\title{
Cold-water coral growth under extreme environmental conditions, the Cape Lookout area, NW Atlantic
}

\author{
F. Mienis ${ }^{1,2}$, G. C. A. Duineveld ${ }^{3}$, A. J. Davies ${ }^{4}$, M. M. S. Lavaleye ${ }^{3}$, S. W. Ross ${ }^{5}$, H. Seim ${ }^{6}$, J. Bane ${ }^{6}$, H. van Haren ${ }^{7}$,

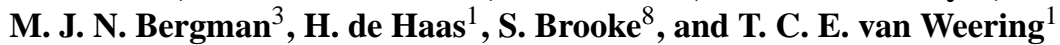 \\ ${ }^{1}$ Royal Netherlands Institute for Sea Research, Department of Marine Geology, P.O. Box 59, 1790 AB Den Burg, \\ the Netherlands \\ ${ }^{2}$ MARUM, University of Bremen, Leobenerstrasse, 28253 Bremen, Germany \\ ${ }^{3}$ Royal Netherlands Institute for Sea Research, Department of Marine Ecology, P.O. Box 59, 1790 AB Den Burg, \\ the Netherlands \\ ${ }^{4}$ School of Ocean Sciences, Bangor University, Isle of Anglesey, LL59 5AB, UK \\ ${ }^{5}$ University of North Carolina-Wilmington, Center for Marine Science, 5600 Marvin Moss Lane, Wilmington, NC 28409, \\ USA \\ ${ }^{6}$ University of North Carolina-Chapel Hill, Department of Marine Sciences, 3202 Venable Hall, Chapel Hill, NC 27599-3300, \\ USA \\ ${ }^{7}$ Royal Netherlands Institute for Sea Research, Department of Physical Oceanography, P.O. Box 59, 1790 AB Den Burg, \\ the Netherlands \\ ${ }^{8}$ Florida State University Coastal and Marine Lab, 3618 Coastal Highway 98, St. Teresa, FL 32358, USA
}

Correspondence to: F. Mienis (furu.mienis@nioz.nl)

Received: 4 November 2013 - Published in Biogeosciences Discuss.: 3 December 2013

Revised: 20 March 2014 - Accepted: 23 March 2014 - Published: 13 May 2014

\begin{abstract}
The Cape Lookout cold-water coral area off the coast of North Carolina forms the shallowest and northernmost cold-water coral mound area on the Blake Plateau in the NW Atlantic. Cold-water coral habitats near Cape Lookout are occasionally bathed in the Gulf Stream, which is characterised by oligotrophic warm water and strong surface currents. Here, we present the first insights into the mound distribution and morphology, sedimentary environment and coral cover and near-bed environmental conditions as recorded by bottom landers from this coral area. The mounds occur between 320 and $550 \mathrm{~m}$ water depth and are characterised by high acoustic backscatter indicating the presence of hard structure. Three distinct mound morphologies were observed: (1) a mound with a flattened top at $320 \mathrm{~m}$, (2) multi-summited mounds with a teardrop shape in the middle part of the area and (3) a single mound at $540 \mathrm{~m}$ water depth. Echosounder profiles show the presence of a strong reflector underneath all mound structures that forms the base of the mounds. This reflector cropped out at the downstream side of the single mound and consists of carbonate slabs. Video anal-
\end{abstract}

ysis revealed that all mounds are covered by Lophelia pertusa and that living colonies only occur close to the summits of the SSW side of the mounds, which is the side that faces the strongest currents. Off-mound areas were characterised by low backscatter and sediment ripples, indicating the presence of relatively strong bottom currents. Two bottom landers were deployed amidst the coral mounds between December 2009 and May 2010. Both landers recorded prominent events, characterised by large fluctuations in environmental conditions near the seabed as well as in the overlying water column. The period between December and April was characterised by several events of increasing temperature and salinity, coinciding with increased flow and near-bed acoustic backscatter. During these events temperature fluctuated by up to $9^{\circ} \mathrm{C}$ within a day, which is the largest temperature variability as measured so far in a cold-water coral habitat. Warm events, related to Gulf Stream meanders, had the duration of roughly 1 week and the current during these events was directed to the NNE. The consequences of such events must be significant given the strong effects of temperature 
on the metabolism of cold-water corals. Furthermore, elevated acoustic backscatter values and high mass fluxes were also recorded during these events, indicating a second stressor that may affect the corals. The abrasive nature of sand in combination with strong currents might sand blast the corals. We conclude that cold-water corals near Cape Lookout live under extreme conditions that limit mound growth at present.

\section{Introduction}

Extensive studies on cold-water corals in the past decades in both the West Atlantic (Reed, 1980, 2002; Paull et al., 2000; Lumsden et al., 2007; Ross et al., 2007a) and the East Atlantic (De Mol et al., 2002; Van Weering et al., 2003b; Huvenne et al., 2005; Roberts et al., 2006) have shown that coldwater coral (CWC) habitats can have different appearances. The most prominent forms are the kilometres long and wide mounds of several $100 \mathrm{~m}$ height that occur along the Irish continental margin (Belgica Mounds; Huvenne et al., 2005) and Rockall Bank (Logachev Mounds; Kenyon et al., 2003; Mienis et al., 2006), and genuine reef forms such as Sula Ridge and Røst Reef (Mortensen et al., 1995; Freiwald et al., 1997). More numerous are CWC habitats of smaller dimensions that often have elongated shapes (or tails) and an orientation parallel to the current direction. Clusters of such structures are found in Norway (Traena; Mortensen et al., 1995), in the Irish Porcupine Seabight (Moira Mounds; Wheeler et al., 2011), and on the UK continental margin (Darwin Mounds; Masson et al., 2003; Huvenne et al., 2009a). This form has been considered as early stages of mound formation. Coral banks with comparable dimensions and morphology have also been described from the West Atlantic off North Carolina (Grasmueck et al., 2006b; Partyka et al., 2007; Ross et al., 2007a; Davies et al., 2010).

Studies on the ecosystem of the large and prominent coral mounds found on the Rockall and Porcupine slopes have clearly demonstrated that these habitats promote biodiversity, benthic biomass and carbon mineralisation (e.g. Jensen et al., 1992; Henry et al., 2007; Van Oevelen et al., 2009). Comparable studies on the living fauna and ecosystem functioning of smaller coral habitats are fewer: for example of the fish community of coral banks on the Blake Plateau (Ross et al., 2007b, 2009) and the meiofauna and foraminifera on the Darwin Mounds (Van Gaever et al., 2004; Hughes et al., 2004). According to Ross and Quattrini (2007) coral banks off North Carolina have a distinctive fish fauna with a high species richness. No effect of topography was found on the nematode meiofauna in the Darwin Mounds (Vanreusel et al., 2010) although the coral skeletons promoted the occurrence of specialised nematode genera in the Porcupine Seabight (Raes et al., 2006). Not only does the ecological importance of clusters of small coral banks need further exploration, but so also do the processes responsi- ble for their origin, persistence and functioning (e.g. erosion, deposition rates, particle supply). Deposition of sediment as a result of baffling by the corals is regarded as crucial for the growth and maintenance of these structures on the Irish continental slope (Dorschel et al., 2005; De Haas et al., 2009; Wheeler et al., 2011). Such knowledge is important in the process of acquiring protection for these vulnerable habitats, most notably against bottom trawling. In the case of the Darwin Mounds (Serpetti et al., 2013) and various reefs in Norway, protection has already been imposed (De Santo et al., 2007; www.fisheries.no), but in other cases this is still pending. The CWC habitats off the southeastern United States, including those studied here, were recently protected by the inclusion in a Habitat Area of Particular Concern (http://safmc.net/managed-areas/deepwater-coral-hapcs).

The main aim of this study is to describe and discuss the mound distribution and morphology, sedimentary environment and near-bed environmental conditions in the coral area near Cape Lookout (North Carolina, USA) and to assess its suitability for cold-water corals and associated megafauna. Here, we present observations and measurements made in June 2010 on a cluster of coral mounds during a cruise with RV Pelagia (Royal NIOZ, the Netherlands). As a follow-up on earlier explorations by Ross and Quattrini (2007, 2009), we made a detailed survey of the bathymetry with multibeam, collected data on the geological setting using penetrating echosounder and box cores, and made a gross analysis of the mega- and fish fauna on the basis of recordings with a tethered video system. Furthermore, near-bed environmental conditions were recorded by long-term mooring deployments (December 2009-June 2010).

\section{Geological and oceanographic setting of the study area}

The Cape Lookout CWC area is situated on the northern part of the Blake Plateau (Fig. 1), which forms a continuation of the Bahama Bank carbonate province (Pratt et al., 1964). The Blake Plateau is a broad flat area, which is bounded in the east by the very steep Blake Escarpment and the BlakeBahama basin. The Blake Plateau consists of a layer of more than $14 \mathrm{~km}$ of sedimentary rocks deposited since the Cretaceous (Sheridan, 1976). At present, the Blake Plateau is a sediment-starved region (Pinet et al., 1981; Pinet et al., 1985) and sediments mainly consist of foraminiferal ooze and pteropod fragments (Pratt et al., 1964; Pinet et al., 1985). In general, material finer than silt is absent, and rippling in the sediments as shown on bottom photographs implies that considerable sorting, reworking and redeposition took place (Gorsline, 1963; Pratt, 1963). Towards the shelf the sediment becomes enriched in quartz and the boundary between the two sedimentological zones is characterised by deposits rich in glauconite and phosphate (Gorsline, 1963). During the Quaternary, sediment deposition and erosion were mainly steered by the Gulf Stream. During sea-level lowstands the Gulf Stream moved offshore, whilst at present, the pathway 


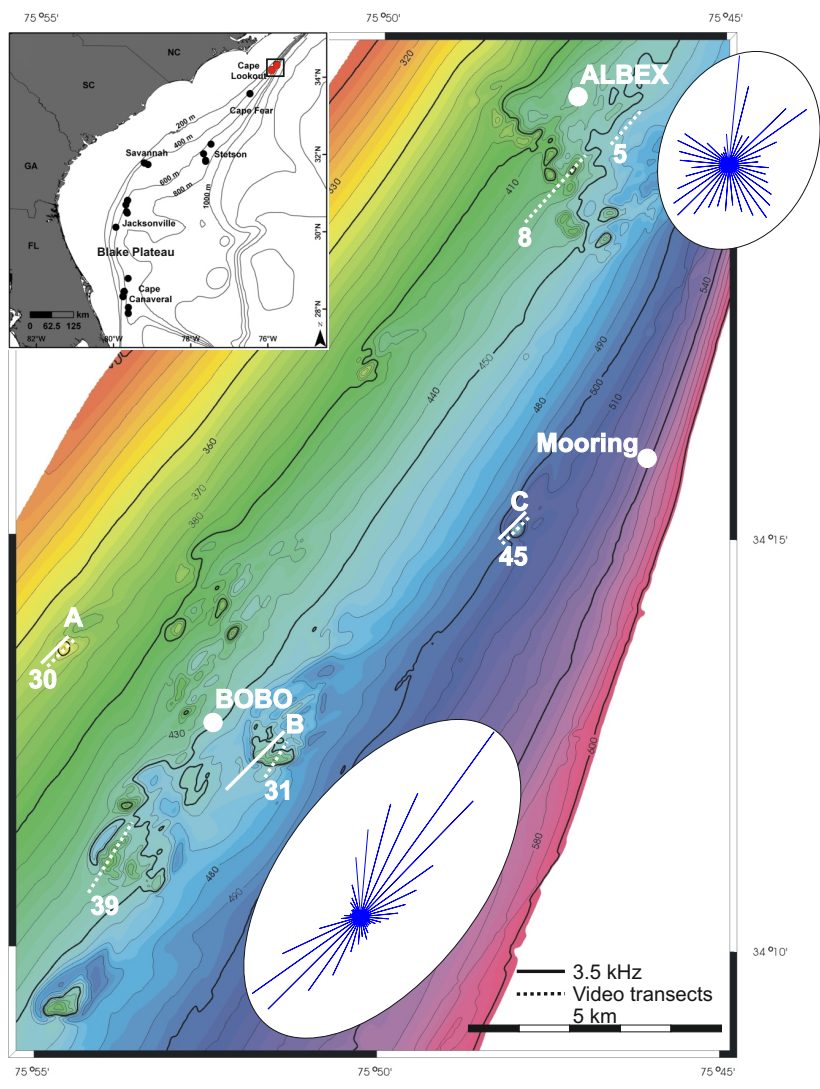

Fig. 1. Multibeam bathymetry map of the research area with $3.5 \mathrm{kHz}$ profiles, video transects, mooring and lander locations indicated. Vector plots of displacement (ellipses) relative to the lander position show the direction and magnitude of the transport of water. Inset shows the general CWC areas that have been recorded in the West Atlantic.

of the Gulf Stream is more inshore (Pratt, 1963; Pinet et al., 1985; Hill et al., 2010).

Stetson (1962) described that numerous coral banks are present at the northeastern portion of the Blake Plateau, and in subsequent years many more CWC habitats have been discovered (Neumann et al., 1977; Paull et al., 2000; Reed, 2002; Partyka et al., 2007; Ross et al., 2007a). This includes the Cape Lookout coral mounds, which form the northernmost CWC mounds on the Blake Plateau.

The CWC habitats on the Blake Plateau are occasionally flushed by the Gulf Stream (Blake et al., 1994; Ross et al., 2009), which is characterised by oligotrophic and warm waters with strong currents. The Gulf Stream is an important agent of heat transport to the poles and flows from the Florida Straits over the Blake Plateau (between 100 and $800 \mathrm{~m}$ water depth) to Cape Hatteras as a meandering jet. Here, the Gulf Stream separates from the coast and flows to the northeast (Matsumoto et al., 2003). While flowing over the Blake Plateau and the Cape Lookout coral mounds the Gulf Stream meanders, causing relatively cool continental shelf waters to be temporarily replaced by warmer Gulf Stream water (Bane et al., 1981).

Biological production on the shelf is strongly influenced by this interaction between the Gulf Stream and adjacent shelf waters (Lee et al., 1991; Garciamoliner et al., 1994; Ryan et al., 1999; Leterme et al., 2008). During meandering, eddies are formed and shed off on both sides of the Gulf Stream; those inshore of the Gulf Stream propagate northwards at an average speed of $0.4 \mathrm{~m} \mathrm{~s}^{-1}$. The inshore wavelike meanders and eddies amplify north of the Strait of Florida and downstream of the Charleston Bump, after which the features dissipate more offshore between 33 and $36^{\circ} \mathrm{N}$. Cyclonic cold core eddies occur when the meander of the Gulf Stream is in an offshore position. They move to the north at the same speed as the meander and have the same size (Bane et al., 1981; Glenn et al., 1994). Upwelling in cold core eddies uplifts the density structure of the front and transports nutrients into the euphotic zone. It is suggested that phytoplankton and bacterioplankton production is strongly influenced by the upwelling intrusion events, which might form an important food source for the CWC habitats on the Blake Plateau (Lee et al., 1991; Leterme et al., 2008).

\section{Methods}

\subsection{Multibeam}

An extensive bathymetric survey with a hull-mounted Kongsberg EM 302 multibeam echosounder on the RV Pelagia was conducted between 31 May and 4 June 2010. The system consisted of a $30 \mathrm{kHz}$ echosounder with an $1^{\circ}$ opening angle for the transmitter and a $2^{\circ}$ angle for the receiver and uses 135 beams with a maximum coverage sector of $150^{\circ}$ (depth range 10-7000 m). This results in a swath width of five times the water depth between 500 and $1000 \mathrm{~m}$ water depth. The transmit fan is split into at maximum nine individual sectors that can be steered independently to compensate for ship's roll, pitch and yaw to get a best fit of the ensonified line perpendicular to the ship's track and thus a uniform coverage of the sea bed. The motion of the vessel was registered by a Kongsberg MRU-5 motion reference unit and the ship position and heading was determined by GPS. Data acquisition was conducted using the Kongsberg Seafloor Information System software. The sound velocity profile was calculated from salinity, pressure and temperature data recorded by a Seabird 911+ CTD system immediately prior to the survey. Bathymetric data were processed using Neptune (Kongsberg) and CFloor (Geocap AS). Backscatter maps of the research area were created using Fledermaus Geocoder which show the amount of backscatter as greyscale. Regions with high backscatter are depicted as light areas. The amount of backscatter depends on a variety of factors like the angle of incidence (for which the data are 
compensated), the sediment composition and the roughness of the seafloor.

\subsection{Predictive habitat mapping}

A regional-scale predictive habitat map was developed with the aim of providing an indication of the relative suitability of the southeast USA region for L. pertusa. Two models were produced using the Maxent software (Phillips et al., 2006), using default parameters following Davies et al. (2011; Maxent version $3.3 .3 \mathrm{k}$ ), an increasingly popular method for predicting suitable habitat for data-poor species in the deep ocean (Davies et al., 2011; Yesson et al., 2012). The environmental variables utilised were initially partitioned into broad groups (bathymetry, biological production, carbonate chemistry, chemical, geological, oxygen, physical oceanography, terrain variables and other), and one variable from each group was retained for the production of the final model based on highest training gains for models built from a single variable following a similar approach presented by Yesson et al. (2012) (full details of each variable source and gain scores are provided in Supplement Table 1). Two models were produced: the first incorporated a substrate type layer constructed from point sample data (see Supplement Table 1), whilst the second model was built without substrate type as this layer greatly constrained the spatial extent of the model due to poor data coverage. Species data were acquired from previously published records collated by Davies and Guinotte (2011). For the sediment-constrained model, 154 records were used to train the model and 65 for the production of test statistics; 179 were used to train the non-sediment model and 76 for test statistics.

\subsection{Echosounder}

Several $3.5 \mathrm{kHz}$ penetrating echosounder lines were recorded using the RV Pelagia echosounder system across and along different mound structures to gain insight into the internal geometry of the mounds. This system consisted of an ORETech 3010 transceiver and a hull-mounted 12-transducer array. The analogue data were digitised with a CodaOctopus DA1000 system running the Coda Geosurvey software and were processed using RadexPro with amplitude correction and Stolt F-K migration.

\subsection{Sediment sampling}

Sediment samples were taken with a NIOZ-designed cylindrical box corer equipped with a stainless steel cylindrical box of $50 \mathrm{~cm}$ in diameter and $55 \mathrm{~cm}$ in height and a trip valve sealing the core after penetration. A camera system attached to the frame allowed video-guided sampling. The surface of each box core was photographed on recovery and a detailed description of the species composition and sediment characteristics was taken.

\subsection{Moored equipment}

Two benthic landers were deployed at Cape Lookout during a cruise with the RV Cape Hatteras (operated by Duke-UNC Oceanographic Consortium) in December 2009. Both landers were successfully retrieved in June 2010 with the RV Pelagia and each lander obtained 6 months of near-bed environmental conditions. The ALBEX lander was deployed in the northern part of the study area at the tail of a mound cluster in $417 \mathrm{~m}$ of water at $34^{\circ} 20.941^{\prime} \mathrm{N}, 75^{\circ} 46.756^{\prime} \mathrm{W}$. The BOBO lander was positioned amidst a cluster of mounds at $480 \mathrm{~m}$ depth at $34^{\circ} 12.680^{\prime} \mathrm{N}, 75^{\circ} 52.204^{\prime} \mathrm{W}$ (Fig. 1).

The ALBEX lander consisted of an aluminium tripod equipped with a 3-D (2 MHz) acoustic current meter (Nortek Aquadopp), a CTD (Seabird SBE37), and a combined optical backscatter sensor and fluorometer (Wetlabs FLNTU). All instruments were mounted $2 \mathrm{~m}$ above the seafloor. The ALBEX lander additionally carried an upward-looking Acoustic Doppler Current Profiler (ADCP, Teledyne RDI $300 \mathrm{kHz}$ ) that measured horizontal currents up to $170 \mathrm{~m}$ above bottom for the entire period. The BOBO lander consisted of an aluminium tripod that extended $4 \mathrm{~m}$ above bottom, creating a clear area underneath the lander for current velocity and acoustic backscatter measurements, which were measured by a downward-looking Teledyne RDI $1200 \mathrm{kHz}$ ADCP mounted at $2 \mathrm{~m}$ above bottom. For this deployment the BOBO lander was equipped with an SBE 16+ CT sensor mounted at $3 \mathrm{~m}$ above bottom, and a combined optical backscatter sensor and fluorometer similar to the one on the ALBEX. All equipment on both landers was programmed to record at 15 min intervals.

Both landers were equipped with a Technicap PPS 4/3 sediment trap with a $0.05 \mathrm{~m}^{2}$ aperture. Sediment traps were equipped with a rotating carousel of 12 bottles of $250 \mathrm{~mL}$. Each bottle collected material for 14 days, and samples were preserved in a $\mathrm{pH}$ buffered $\mathrm{HgCl}_{2}$ solution in seawater, which was collected from the deployment site. All samples were split with a rotor splitter and two splits were freeze dried after which total matter was weighed and mass fluxes were calculated. All sediment trap samples of the BOBO lander were analysed for organic carbon, nitrogen content, pigment content and ${ }^{210} \mathrm{~Pb}$. Detailed descriptions of the methods can be found in Mienis et al. (2012).

In addition to the landers, a mooring was deployed in December 2009 at a depth of $550 \mathrm{~m}$ at $34^{\circ} 16.023^{\prime} \mathrm{N} / 75^{\circ} 45$. $9216^{\prime} \mathrm{W}$ outside the $\mathrm{CWC}$ area. The mooring was composed of a bottom weight $(660 \mathrm{~kg})$, two acoustic releases and a Valeport current meter ( $160 \mathrm{~m}$ above bottom).

\subsection{Tethered video imaging and analysis}

Video recordings of the coral habitats in the Cape Lookout CWC area were made using a tethered camera system attached to the box corer frame. The camera system consisted of a digital video camera $\left(\right.$ Sony ${ }^{\mathrm{TM}}$ ), hard disk, power supply, 
modem, lights, and a set of parallel green laser pointers set $30 \mathrm{~cm}$ apart $\left(\right.$ Oktopus $\left.^{\mathrm{TM}}\right)$. Live video images were transferred to the ship by the modem via the conductive core of the wire holding the box corer frame. This connection enabled the winch operator to keep the camera system at more or less constant distance from the seafloor assisted by the distance marks made by lasers. A total of eight video surveys were made along transects in a SSW to NNE direction crossing coral mounds that were visible on the multibeam map. The length of each transect varied between 1.4 and $4.8 \mathrm{~km}$ and started and ended in an off-mound position thereby covering coral as well as non-coral habitats. The video records were used to ground-truth both reef and sedimentary structures observed on the multibeam data and echosounder profiles and to make a gross description of the distribution of corals, invertebrate epifauna and fishes in relation to these structures. For the purpose of this study we have identified organisms to higher taxonomic levels. Detailed analyses of the diversity and abundance of invertebrates and fish species recorded on the video will be presented elsewhere. The video quality precluded in many cases rapid identification to species level. The quality issue was the result of the extremely strong surface currents in the Gulf Stream impeding manoeuvrability of the vessel and operation of the tethered camera system.

To describe the fauna along each transect, transects were initially divided into sections of $50 \mathrm{~m}$ length, and the presence/absence of groups of organisms in these sections was noted. Fishes were enumerated with a distinction between cartilaginous (Chondrichthyes) and bony fishes (Osteichthyes). Simultaneously the predominant substratum in each $50 \mathrm{~m}$ section was assigned to one of the following operational categories: (1) soft sediment, (2) sediment partly to densely covered with coral rubble and/or dead framework, (3) well developed (3-D) but predominantly dead framework with scattered live branches, (4) well developed framework with coalescent live branches, (5) stones/hard rock. Video sections in each transect were subsequently grouped according to predominant substratum, and organism counts were summed and averaged over the number of sections in each group.

\section{Results}

\subsection{Predictive habitat mapping}

The predictive models revealed that the southern parts of the eastern US slopes (Florida, Georgia and South Carolina coasts) contained the majority of suitable habitat for L. pertusa relative to the north of North Carolina (Fig. 2). Both the sediment-constrained (Fig. 2a) and non-sediment (Fig. 2b) models performed well with high test AUC scores $(0.951$ and 0.942 , respectively), low omission rates ( 8 and $7 \%$, respectively) and high test gains (2.070 and 1.852 , respectively). The sediment-constrained model performed better

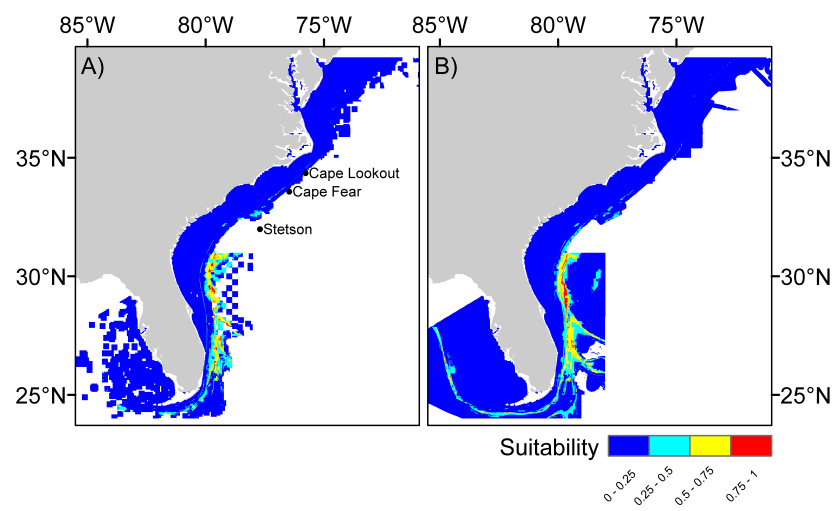

Fig. 2. Habitat suitability models for L. pertusa in the southeastern US shelf: (A) a model created using sediment type and (B) a model without sediment incorporated. The larger area of the non-sediment layer is a result of the limited sediment data available for the region. Higher suitability values indicate that the area is more suitable for coral occurrence but do not mean that corals will be found there as there may be other variables constraining occurrence that are not used in the model.

than the non-sediment constrained model even though the contribution of the sediment layer was low (test gain 0.337 and AUC 0.690 for a model constructed of only sediment type). Based on the regularised training gain, the most important variable was depth for both models, followed by aragonite saturation and dissolved oxygen concentration. The variable that decreased the gain the most when omitted, and therefore contains information not present in other variables, was particulate organic carbon concentration for the non-sediment constrained model and current speed for the sediment-constrained model. However, sediment type decreased the gain by almost an equal amount.

\subsection{Distribution of mounds and mound morphology}

A total area of $750 \mathrm{~km}^{2}$ with a water depth ranging between 240 and $1540 \mathrm{~m}$ was mapped with the multibeam echosounder (Figs. 1 and 3). Up to ten large ( $>30 \mathrm{~m}$ high) and several small CWC mound structures were observed between 320 and $550 \mathrm{~m}$ water depth. Mound structures were characterised by high backscatter, which can be related to the presence of living coral colonies and coral debris as was observed in video images (bright areas in Fig. 3b). Off-mound areas had low backscatter values (darker areas in Fig. 3b) and are largely characterised by sandy sediment. Current ripples were often observed in video images from off-mound areas, indicating high near-bed flow velocity. In the study area three distinct mound morphologies were observed, which appeared related to water depth and can be broadly grouped into upper, mid and deep parts of the mound area. The shallowest mound, which was present at $320 \mathrm{~m}$ water depth, had a flattened top and was up to $40 \mathrm{~m}$ high (Fig. $4 \mathrm{a}$ ). Mounds situated in the intermediate part of the area were characterised by a 

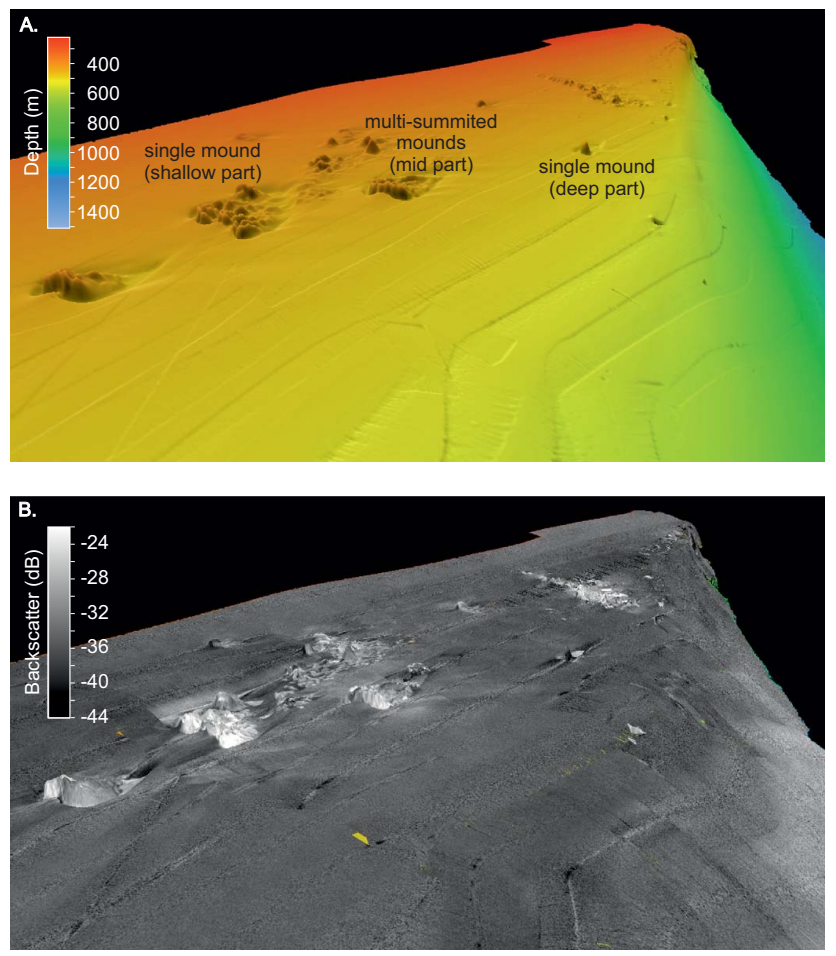

Fig. 3. 3-D multibeam bathymetry (A) and backscatter map (B) of the research area. Different mound morphologies were observed on the shallow, mid and deep part of the mound area. Mounds are characterised by high backscatter (bright areas).

teardrop shape and all had an erosional gulley at the SSW (up-current) side and a sediment moat at the NNE (downcurrent) side of the mound. These mounds had an irregular and rugged topography with multiple summits that are up to $40 \mathrm{~m}$ high. All mounds in the intermediate part of the study area are oriented in a SSW-NNE direction (Fig. 4b). The deepest mound at $520 \mathrm{~m}$ water depth in the area had a different morphology and can be described as a single mound of $0.5 \mathrm{~km}$ in diameter and up to $70 \mathrm{~m}$ high. The single mound was characterised by very steep slopes and an erosional moat at the NNE side (Fig. 4c).

Echosounder surveys crossing the different mound structures revealed that all mounds had a chaotic and almost transparent internal acoustic facies pattern (Fig. 4). Beneath each mound there was a strong reflector that formed the base of the structures. On the down-current side of the deepest mound this reflector cropped out at the surface and video data showed that it was related to a hard substrate formed by carbonate slabs (Figs. 4c and 6).

\subsection{Video data analysis}

The distribution of faunal groups within each classified habitat type is summarised in Fig. 5, and the representative features of each habitat are shown in Fig. 6. All transects started and ended in off-mound habitat (Fig. 1), which in most cases consisted of rippled sand with a coarse or gravelly character and numerous burrows (possibly of squat lobsters). Box cores taken in these off-mound habitats are characterised by well-sorted foraminiferal sand with pteropod fragments. Several of the mounds, i.e. transects 31,39 and 45 , were surrounded by a moat that was also visible on the multibeam and echosounder data (Figs. 3 and 4). Video recordings from the elevated parts of mounds revealed predominantly dead coral framework with occasional thickets of living coral (Fig. 6). Live framework was most abundant on the upper (SSW) slopes facing into the Gulf Stream current. In between the coral thickets, patches of softer and finer sediment with coral rubble were visible which was also observed in box corer samples taken on top of the mound. These samples consisted, down core, of sediment, coral (L. pertusa) and shell debris characteristic of organic mound buildup. The deepest mound (transect 45) had the most extensive patches of live coral framework on its upstream side and also had a different structure of the mound tail. Whilst the other mounds had tails consisting of sediment mixed with $L$. pertusa rubble, the tail of transect 45 was bare of sediment exposing slabs of hard ground (Fig. 6).

A common feature of all video transects was the presence of large numbers of planktonic organisms near the bottom such as euphausids and jellyfish. On several occasions the view of the camera was blocked by euphausids that were attracted by the lights of the camera upon arrival at the seafloor. Transect 5 did not cross a mound as did the other transects. There were marked differences with respect to distribution of taxa including live coral framework between transects. For example, anthozoans (Actinoscyphia sp.) and asteroids (Brisingidae) were only widespread (and abundant) on the shallowest transect 30 while this was the case for galatheids (Munida sp.) on transect 39, and hydrocorals on transect 45. Sponges were not abundant and were only observed on the multi-summited mounds in the middle part of the area. Live coral framework was only observed at the mound structures, and was most common on transect 45 and least present on transect 30 . Transects also differed with respect to abundance of fishes with the deepest transect 45 having highest number of fishes per $50 \mathrm{~m}$ of video (Fig. 7). Average fish numbers of the $50 \mathrm{~m}$ sections of the video surveys were not only relatively high in the coral framework of transect 45 but also across the mound tail with its exposed hard ground.

\subsection{Overlying circulation}

The $300 \mathrm{kHz}$ upward-looking ADCP mounted on the ALBEX lander measured horizontal currents up to $170 \mathrm{~m}$ above bottom. Velocities recorded before mid-April 2010 and afterwards had a different character (Fig. 9). Pulses of strong NNE flow occurred in mid-December 2009, early January 2010, mid-February 2010 and early and mid-March 2010. These pulses coincided with increasing water temperatures of up to $15.8^{\circ} \mathrm{C}$. In early April a sustained SSW flow of 

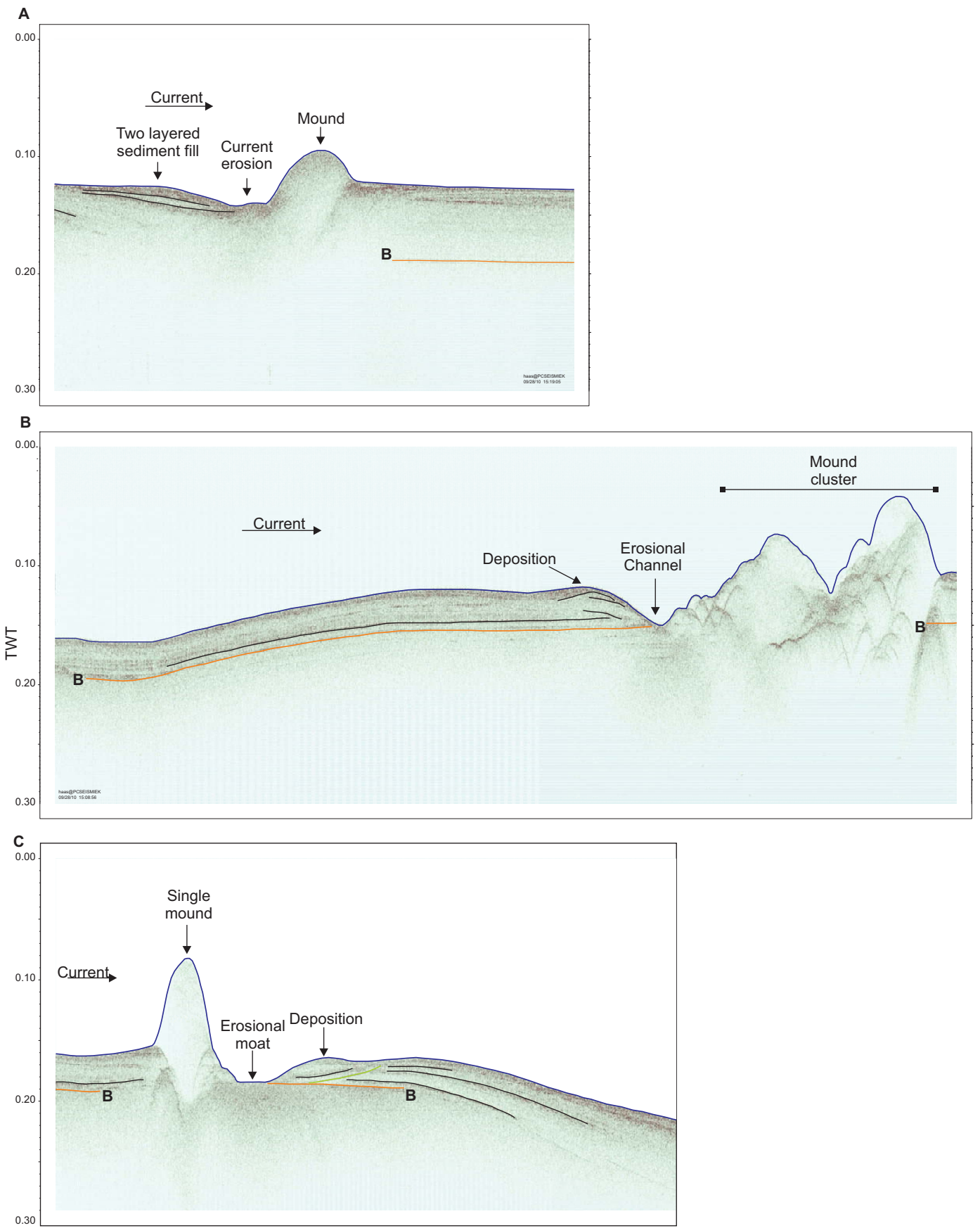

Fig. 4. $3.5 \mathrm{kHz}$ lines (positions of lines are shown in Fig. 1) recorded in a SW-NE direction (A-C), showing the different mound types in the upper, mid and deep part of the Cape Lookout CWC area. (A) Single mound at the upper slope. (B) Multi-summited mounds in the mid slope area. (C) Single mound in the deep area. Underneath the mounds a strong reflector was observed that forms the basement of the mounds (orange line).

$0.4 \mathrm{~m} \mathrm{~s}^{-1}$ was present, whereas a weaker flow was observed after mid-April and persisted until the recovery of the landers in June. Average current speed was $0.29 \mathrm{~m} \mathrm{~s}^{-1}$ to the NNE and $0.13 \mathrm{~m} \mathrm{~s}^{-1}$ to the SSW, whereby a NNE flow was slightly more common over the deployment time period. The average vertical structure of the current varied with current direction, with nearly constant vertical shear of the horizontal current over the lower $100 \mathrm{~m}$ above bottom during NNE flow and a $40 \mathrm{~m}$ thick bottom boundary layer overlain by vertically homogeneous flow speed during SSW flow.

Elevated values of acoustic backscatter were observed in December 2009, February 2010 and from mid-April to late 


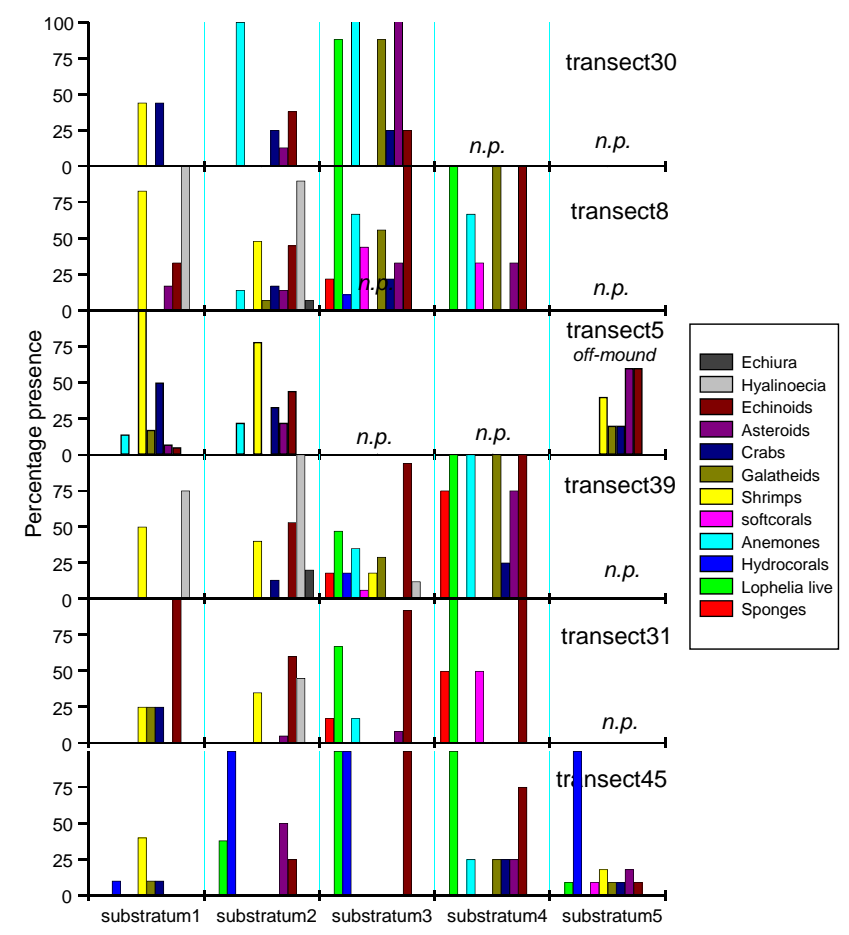

Fig. 5. Faunal assemblages of the video transects for each of the five recognised substrata $(1=$ soft sediment, $2=$ sediment partly to densely covered with coral rubble and/or dead framework, 3 = welldeveloped (3-D) but predominantly dead framework with scattered live branches, $4=$ well-developed framework with coalescent live branches, $5=$ stones/hard rock). The abundance of each faunal group is indicated as a percentage of presence at the $50 \mathrm{~m}$ sections of the whole video transect. The locations of the transects are indicated in Fig. 1.

May 2010 (Fig. 8). Furthermore, a daily migration is observed in the acoustic backscatter. The location of these signals, well removed from the seafloor and the ocean surface, the acoustic frequency $(300 \mathrm{kHz})$ and the observed daily migration suggest zooplankton as the most likely signal source.

\subsection{Near-bed environmental conditions}

The records collected by the two bottom landers and mooring are similar in appearance and display the same warm events also recorded by the upward-looking ADCP. The lander records before April 2010 were characterised by six pronounced events consisting of peaks in temperature up to $15.2^{\circ} \mathrm{C}$ and salinities rising to 36.05 , coinciding with increased flow and acoustic backscatter, which is likely related to resuspension of sediments (Fig. 9). During these events the current was directed to the NNE and bottom-water temperatures increased by up to $9.5^{\circ} \mathrm{C}$ within a day $\left(5.8-15.2^{\circ} \mathrm{C}\right.$; Fig. 11c), while salinity rose from 34.87 to 36.05 . These warm-water events lasted roughly 1 week. Minimum temperatures $\left(5.56-8.33^{\circ} \mathrm{C}\right)$ occurred in May 2011 when currents were relatively weak and directed to the SSW. The sim- ilarity between measurements by the two landers indicates that events are not local in scale but apply to the wider area (Fig. 9). This is further substantiated by the match between the lander temperature records and that obtained by the mooring, deployed in $550 \mathrm{~m}$ water depth.

The fluorescence pattern records were similar on both lander locations (Fig. 9), showing one prominent but short peak in early March, on the onset of a warm event. Acoustic and optical backscatter demonstrate different patterns. Acoustic backscatter increases with each warm event (Fig. 10), whilst optical backscatter only shows prominent peaks in December and February. High backscatter peaks correspond to high mass fluxes as collected with the sediment trap (Fig. 11b and f). The event in February completely filled a sediment trap bottle on the ALBEX lander. During both periods of high mass flux, organic carbon values and pigment concentrations were low, as well as ${ }^{210} \mathrm{~Pb}$ values, which indicates resuspension of aged or degraded material (Fig. 11d-f).

Vector plots of displacement show the transport direction and magnitude of water at both lander locations during the deployment period (Fig. 1). Directions of water transport at both deployment sites have a mainly SSW-NNE orientation, which corresponds with the elongation of the mound structures in the middle part of the area. Strongest currents have an orientation in a NNE direction. The transport direction of water at the ALBEX site is likely influenced by topographic steering of water between the different summits of the mound structure, as it was deployed on the down-current side of a mound structure in the intermediate part of the research area.

\section{Discussion}

\subsection{Mounds}

The Cape Lookout CWC area is mainly characterised by multi-summited CWC mounds that have a teardrop morphology and are oriented in a SSW-NNE direction. Singlemound structures were only observed in the shallowest and deepest part of the mound area. All structures have an erosional moat at their up-current site, indicating the presence of a very strong NNE-directed current in the area, and a sediment tail at the down-current side of the mounds that mainly consists of coral rubble. This same mound morphology was described by Quattrini et al. (2012) for a large CWC mound (Cape Fear Mound) located about $80 \mathrm{~km}$ southwest of the Cape Lookout mounds. The impression that the mounds are subject to a regime with strong currents is confirmed by the presence of current ripples visible on video transects made in off-mound areas, which were also observed during earlier studies on the Blake Plateau (Pratt, 1963). Current ripples had orientations that suggest a predominant NNE transport direction, which can be related to the current direction of the Gulf Stream. The mounds were dominated by the framework-forming scleractinian coral L. pertusa, whilst 


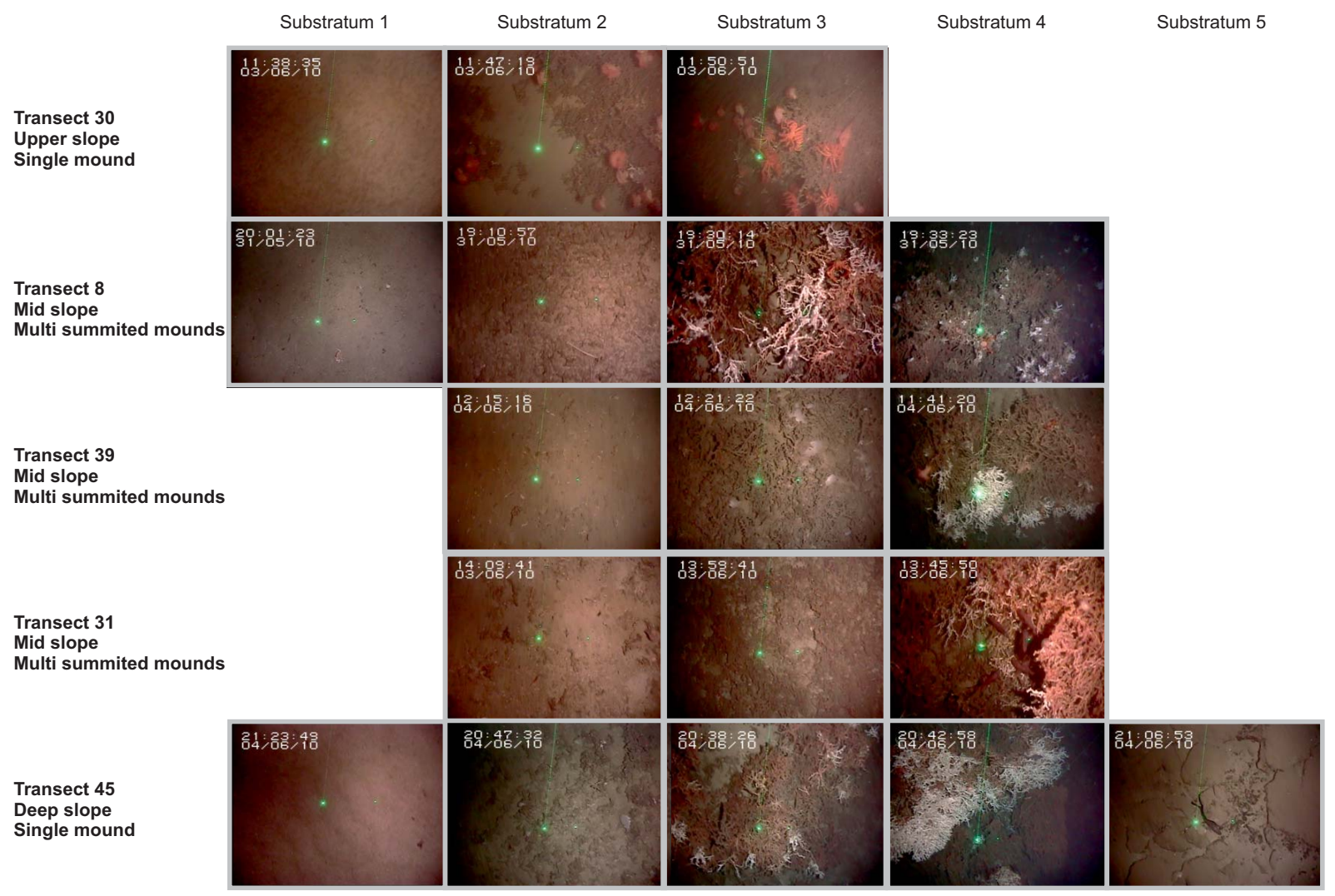

Fig. 6. Still images taken from the video transects characterising different substratum types. For explanation of the substrata numbers see Fig. 5.

stylasterids were also found on the deepest single mound in the area (Fig. 4c). Living CWC colonies were mainly observed on the SSW sides of mounds. Similar mound structures have been found in the Florida Strait (Grasmueck et al., 2006a; Correa et al., 2012), on the continental margin of Norway (e.g. Stjernsund and Traena; Freiwald et al., 1997; Tong et al., 2013) and Tisler Reef (Lavaleye et al., 2009; Guihen et al., 2013). In all these areas elongated reef structures and a strong uni-directional current are present. Several studies have indicated that near-bed currents and turbulence are one of the most important factors influencing coral growth (White et al., 2005; Dorschel et al., 2007; Duineveld et al., 2007; Mienis et al., 2007; Davies et al., 2009). Strong currents will influence the (food) particle encounter rate, which is highest at the current facing sides of the mounds in the Cape Lookout area and elsewhere (Purser et al., 2010). Consequently, mounds and reefs in these areas are likely growing against the currents in a more horizontal manner creating relatively low structures.

A distinct difference was observed not only in mound morphology between the different depth zones with coral mounds, but also in faunal abundance and diversity. Living L. pertusa colonies were not observed on the shallowest single mound, but were instead most frequent on the deepest single mound. The frequency of occurrence of invertebrate megafauna measured by absence/presence per $50 \mathrm{~m}$ strip did not show a clear-cut relation with depth but was higher in substrate types 3 and 4 (coral framework) than in substrate types 1 and 2 representing bare sediment and coral rubble, respectively (Wilcoxon matched pairs test, $p<0.05$ ). A more detailed analysis of the megafauna species abundances will be published separately but our current provisional analysis indicates that several transects have characteristic taxa, e.g. brisingid starfishes on transect 30 and galatheoid crabs on transect 39. Also fishes had a markedly uneven distribution with highest numbers on and around the deepest single mound in the area (transect 45, Fig. 7). So despite the fact that the major environmental perturbations (temperature, current peaks) cover a wide scale encompassing all transects, the fauna distribution suggest local variability most likely related to conditions important for development of coral framework.

The reflection pattern acquired by echosounder profiles of the mounds off Cape Lookout is similar to previously published seismic data of mounds in the northeast Atlantic (Akhmetzhanov et al., 2003; Van Weering et al., 2003a; Mienis et al., 2006). They mainly show chaotic and transparent reflection patterns (Popenoe, 1994), indicating that the mound structures are completely made of cold-water 


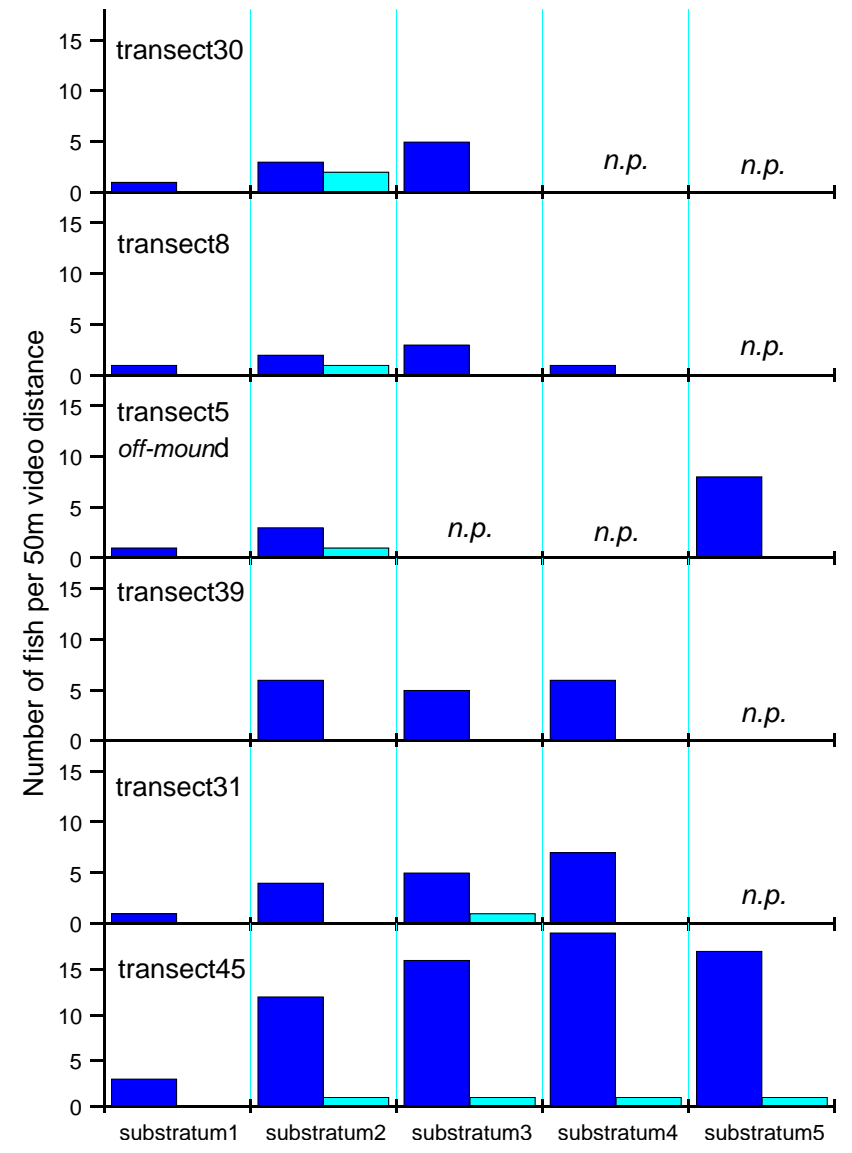

Fig. 7. Average fish abundance as counted for each $50 \mathrm{~m}$ section along the video transects for each substratum. For explanation of the substrata numbers see Fig. 5.

corals and sediments that have been baffled within the coral framework. Underneath the mounds a strong reflector was observed that seems to form the base of all mounds near Cape Lookout. This reflector cropped out behind the deepest mound in the area and video images showed the reflector to be carbonate slabs. CWC mounds on the Blake Plateau have developed in a generally erosional regime where preHolocene to Cretaceous strata are often exposed (Pinet et al., 1981, 1985; Popenoe, 1994). A similar cemented pavement was also observed by Paull et al. (2000) at the seafloor on the Florida-Hatteras slope. One of the requirements for CWC growth is the presence of a stable substrate for settlement. Mounds in the Porcupine Seabight and on the Rockall Trough margins all seem to have initiated on top of a firm ground (Van Rooij et al., 2003; Mienis et al., 2006; Huvenne et al., 2009b). The distribution of the coral mounds near Cape Lookout could be related to sites where the hard ground was exposed during the initial settlement of cold-water corals.

Compared to CWC mounds on the Irish margin that can be kilometres long and wide and up to $360 \mathrm{~m}$ high, the mounds off Cape Lookout are relatively small. This can be either interpreted as the initial phase of mound growth in the area or

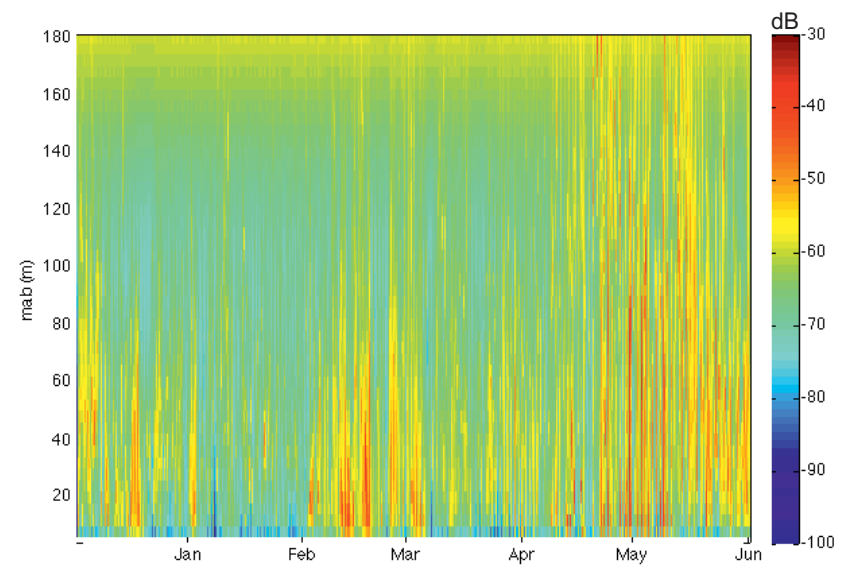

Fig. 8. Acoustic backscatter from the upward-looking ADCP on ALBEX lander, expressed as backscatter strength in $\mathrm{dB}$, following Deines (1999). Orange colours mean more backscatter (e.g. caused by zooplankton).

as an indication that corals are living under stressed conditions, giving rise to a low rate of mound development. Mound growth is mainly due to coral colonies that baffle sediment. If coral growth is outpacing sedimentation, mound structures can form but if the corals are frequently stressed and do not outpace sedimentation then mounds will become relatively limited in size (De Haas et al., 2009; Dorschel et al., 2009).

Retarded coral growth due to stressful conditions seems the most plausible explanation for the small dimensions of the Cape Lookout mounds. Firstly, there is evidence of erosion in the form of moats and exposed hardrock. Secondly, coral ages seem to be higher than in eastern Atlantic areas with mound development. Coral fragments collected at mounds from the Blake Plateau were dated with ages $>20 \mathrm{kyr}$ and very recent datings of CWC fragments from the Cape Lookout even show ages older than $123 \mathrm{kyr}$ (L. Matos, personal communication, 2014). This shows that cold-water corals were already present before the Holocene as opposed to coral reefs found on the Norwegian margin that show rapid development during the Holocene (Freiwald et al., 1997; Lopez Correa et al., 2012). Thirdly, the predictive models (Fig. 2) also suggest that this is a stressful area for corals, as the northern US shelf appears less suitable for coral growth than further south along the Florida margin. Finally, the in situ measurements by the landers showed recurring temperature peaks which are outside the range frequently reported for L. pertusa (see below) (Roberts et al., 2006; Davies et al., 2011).

\subsection{Environmental conditions}

Cold-water corals off Cape Lookout live in an area that is characterised by extreme environmental conditions, which are mainly related to the occasional presence of the Gulf Stream. A clear difference was observed in current velocities 


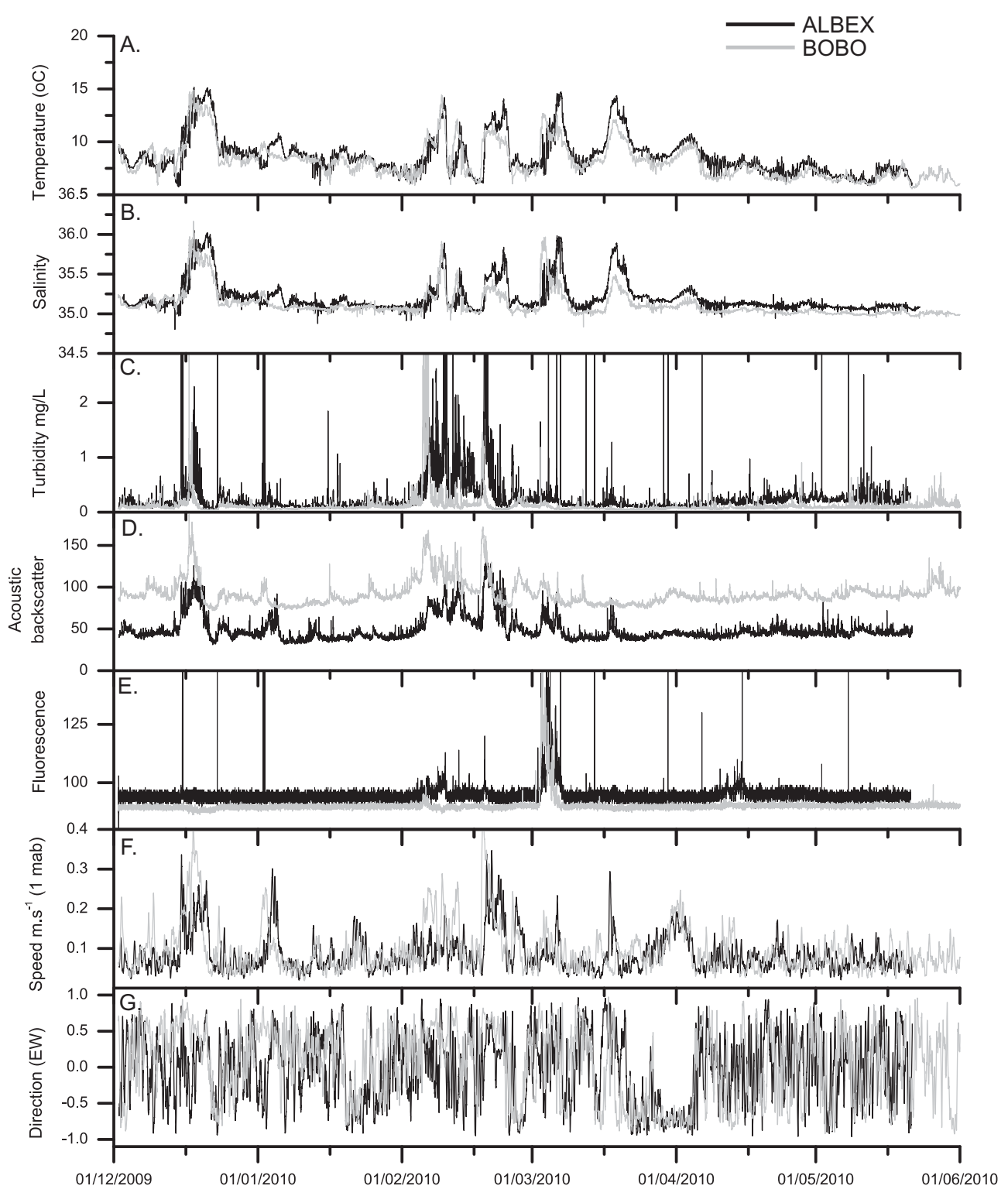

Fig. 9. Six-month records (December 2009-May 2010) from instruments mounted on ALBEX and BOBO benthic landers. (A) Temperature, (B) salinity, (C) turbidity calculated from optical backscatter, (D) acoustic backscatter, (E) fluorescence in relative units, (F) current speed at ALBEX deployment site at height of $2 \mathrm{~m}$ (black line) and at $40 \mathrm{~m}$ (grey line) above bottom, (G) current direction at ALBEX deployment site. In (A-E) the ALBEX data are shown as black lines, and BOBO data as grey lines.

before and after April 2010. Before April 2010, several strong pulses of NNE flow were observed, which coincided with increasing temperatures and high near-bed acoustic backscatter values. After mid-April 2010, current velocities were much lower and minimum temperatures were observed. Sea-surface temperature data obtained from satellite imagery at the end of the first strong NNE pulse (Fig. 12) suggest that the Gulf Stream was atop the mooring and mooring sites during this time and presumably during other times of strong NNE flow. The more-shoreward position of the Gulf Stream at the lander locations at that time was due to a wavelike
Gulf Stream meander progressing towards the NE. The crest of the meander was directly over the mooring site on 17 December 2009. Two SST images from March show the effect of the transition from NNE to SSW flow (Fig. 12). A deflection (an almost right angle turn) of the Gulf Stream developed at the end of April, which we associate with a period of stronger SSW flow (Fig. 12). It appears that this deflection moved slowly downstream, but the general location of the Gulf Stream remained offshore of the mooring site from this time until the end of the deployment. Other SST images are consistent with the Gulf Stream remaining well offshore 

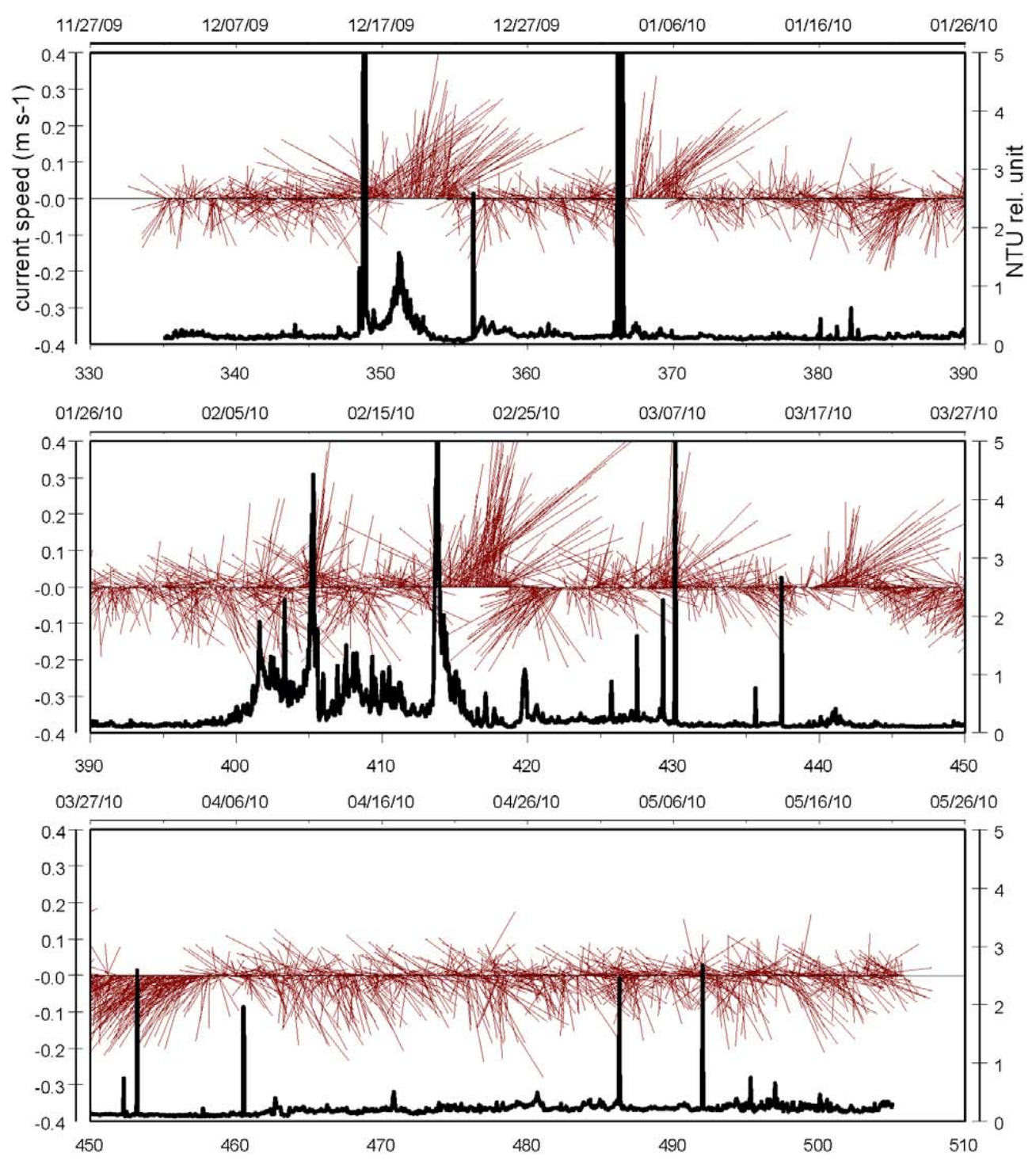

Fig. 10. Current speed and direction (stick plot), in combination with turbidity during 6-month deployment. The lower $x$ axis gives days since 1 January 2009, while the upper $x$ axis gives the true dates.

of Cape Lookout until the recovery of the moored instrumentation (Fig. 12).

Regular coastward meanders of the Gulf Stream led to a rapid rise in bottom water temperature of up to $9{ }^{\circ} \mathrm{C}$ and salinity by up to 1.18 , which are the largest temperature and salinity variabilities so far measured directly within a CWC habitat. The metabolic consequences of these pulses must be significant given the strong effects of temperature on the respiration of cold-water corals and particularly $L$. pertusa. For example, a rise of almost $10^{\circ} \mathrm{C}$ in temperature will lead to a more than fivefold increase in coral respiration $\left(Q_{10}=5.4\right.$ 7.8) (Dodds et al., 2007). Prolonged periods of high temperatures will require an equivalent increase in food availability to account for the increased basic demand of corals and other benthic organisms in the region. Naumann et al. (2014) have evaluated the effect of changing temperatures on the physiology of the two most common framework-building coral species. Their experiments showed that respiration and calcification rates of $L$. pertusa were less affected by changes in temperature compared to Madrepora oculata. Furthermore, $L$. pertusa needed a shorter acclimation time, which might be favourable in light of the large temperature fluctuations as observed off Cape Lookout. Additionally, Brooke et al. (2013) demonstrated that $L$. pertusa may have a somewhat higher temperature tolerance than was previously reported with an upper lethal boundary near $15^{\circ} \mathrm{C}$ (Brooke et al., 2013). This might explain why only $L$. pertusa was commonly present on CWC mounds on the Blake Plateau (Neumann et al., 1977; Paull et al., 2000; Reed et al., 2006; Quattrini et al., 2012). However, enhanced metabolic activity must 


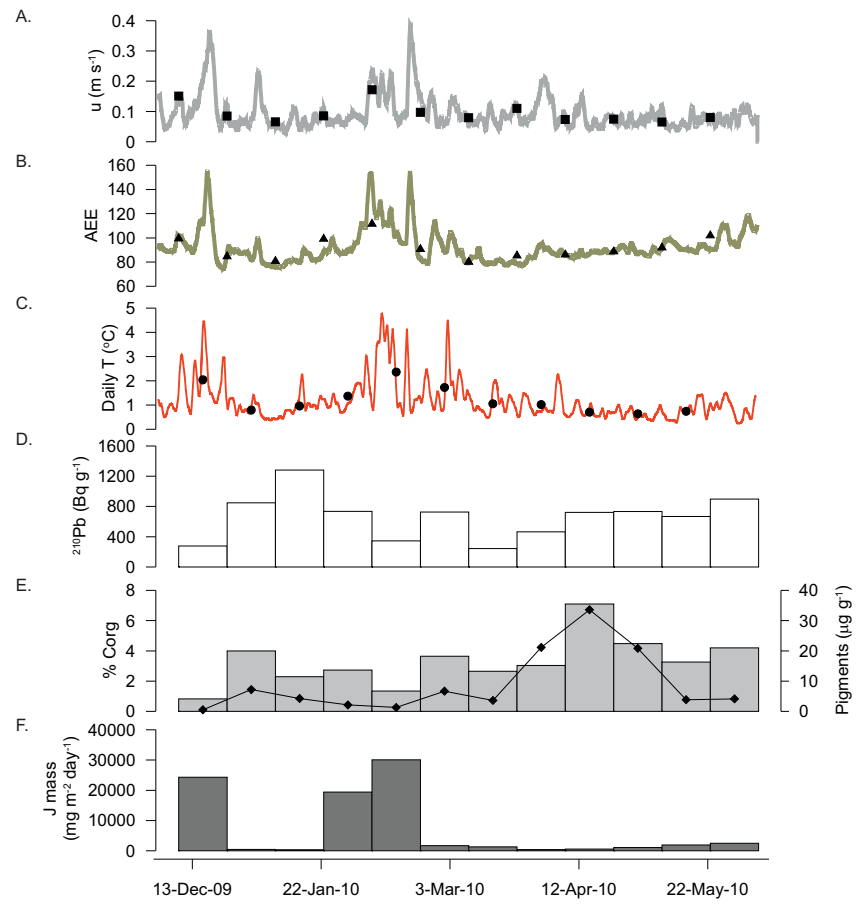

Fig. 11. Record of daily (line) and 16-day average (dots) of fluctuations of (A) current speed, (B) acoustic backscatter, (C) temperature (daily $\Delta T),(\mathbf{D})$ organic carbon $(\%)$ and pigment concentration $\left(\mu \mathrm{g} \mathrm{g}^{-1}\right),(\mathbf{E})^{210} \mathrm{~Pb}\left(\mathrm{Bqg}^{-1}\right),(\mathbf{F})$ total mass flux $\left(\mathrm{mg} \mathrm{m}^{-2} \mathrm{day}^{-1}\right)$.

be compensated for by energy intake. Therefore, particle supply and quality play an equally important role in the distribution of L. pertusa (Duineveld et al., 2004; White et al., 2005; Mienis et al., 2007; Davies et al., 2009).

According to earlier studies vertical instabilities along the westward boundary of meanders give rise to filaments and eddies with associated nutrient entrainment and enhanced plankton production (Lee et al., 1991; Garciamoliner et al., 1994; Matrai et al., 1996; Ryan et al., 1999, 2001; Leterme et al., 2008). In 6 months only a single fluorescence peak was recorded (early March 2010) near the seabed that coincided with a passing meander. Otherwise, no increase of fluorescence was observed during the warm-water events near the seabed. This peak in fluorescence could be related to a spring bloom that occurs in winter due to deep dense water mixing (Leterme et al., 2008) or to shelf-break upwelling in response to wind stress during unstratified periods (Ryan et al., 1996). During many of the warm events the benthic community could experience food stress due to enhanced metabolic demands and the lack of fresh, high-quality food in the form of phytodetritus. This may explain the box corer and video observations showing relatively low proportions of live coral and scarcity of epifauna, especially of large macrosponges as compared to coral habitats in the E Atlantic (Rockall Bank, Porcupine Seabight, Norwegian reefs) (Van Soest et al., 2007). By contrast, CWC habitats in the eastern Atlantic have a rich sponge fauna (Van Soest et al., 2007), as well as some reefs in the western Atlantic, e.g. in the Jacksonville, Cape Canaveral and Florida areas (Partyka et al., 2007).

Lack of phytodetritus could be compensated for by other food sources. Cold-water corals can also feed on zooplankton or nutrients derived from zooplankton (e.g. faeces) (Duineveld et al., 2007; Kiriakoulakis et al., 2007; Becker et al., 2009). Cold-water corals have been shown to capture live prey (Hovland et al., 1999). The increased mid water column acoustic backscatter values recorded by the lander ADCP in the December, February, April to May time period, may point to either greater abundance of scatterers (zooplankton) or a change in the scatterers (e.g. different species). Furthermore, the view of the tethered camera was on several occasions blocked by large numbers of euphausids attracted by the light. It is possible that these could provide an alternative food source for corals and perhaps other benthic fauna. Given the extreme nature of conditions at Cape Lookout, and the differences with other coral habitats, food supply studies are particularly needed to provide further insight into the tolerance and prospects of the local CWC communities.

Gulf Stream meanders coincided with current velocities of up to $0.6 \mathrm{~m} \mathrm{~s}^{-1}$ and increased near-bed acoustic backscatter at both lander locations. These increases indicate resuspension of relatively coarse particles, given that the current meters on the landers are more sensitive to larger $(160-320 \mu \mathrm{m})$ particles (Mienis et al., 2012). The instantaneous increases in the acoustic backscatter up to $35 \mathrm{~m}$ above the seafloor, at the onset of warm events when the current speed increases (Fig. 9), could represent local erosion of the seafloor in offmound areas and deposition of large amounts of sediment on the coral mounds. Sediment in off-mound areas consists of relatively coarse carbonate sand. This was also shown by the large amounts of sediment that were collected in the sediment trap as compared to other coral areas (Mienis, et al. 2009; Mienis, et al. 2012). The ${ }^{210} \mathrm{~Pb}$, organic carbon and pigment data show that during resuspension events mainly old or degraded material is being resuspended. Such erosion and deposition could explain our observation of partly buried and sediment-filled framework on top of the mounds. These resuspension events, which last up to a week, might form another stressor affecting coral growth. Although cold-water corals can handle high sediment load for prolonged periods (Brooke et al., 2009; Larsson et al., 2013), the abrasive nature of sand in combination with strong currents can have a negative effect on living cold-water colonies that are present on the Gulf Stream facing flanks of the mounds. Subsequently, during these periods corals will likely not be able to feed at an optimal or sufficient rate (Purser et al., 2010). 

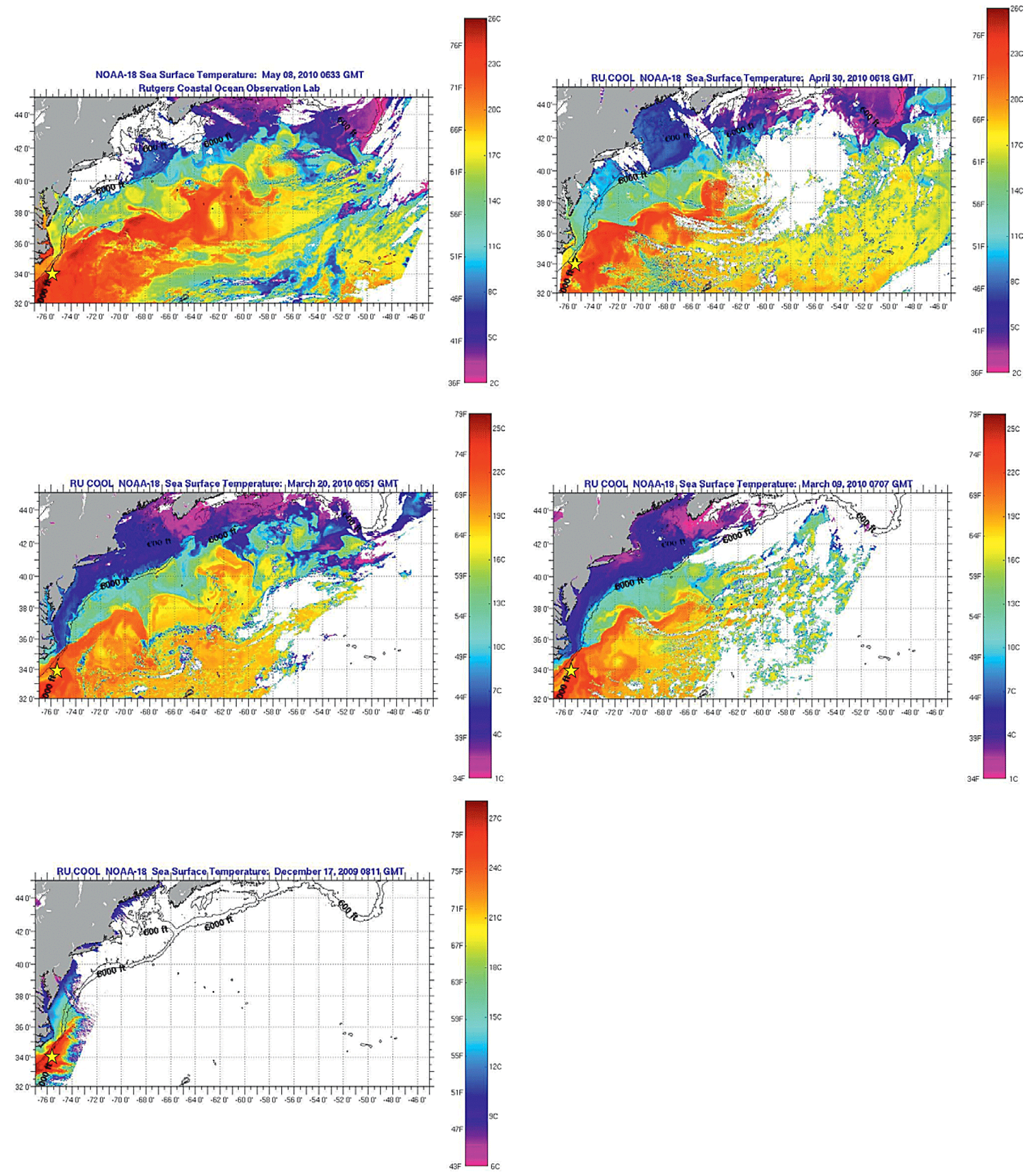

Fig. 12. SST satellite images of sea-surface temperature distribution in the NW Atlantic on 17 December 2009, 9 and 20 March, 31 April and 8 May 2010 (http://marine.rutgers.edu/mrs/sat_data/). The position of the Gulf Stream and its influence on the study area off central North Carolina is clearly visible.

\section{Conclusions}

Cold-water corals off Cape Lookout live under extreme environmental conditions that potentially limit coral and therefore mound growth. Largest temperature and salinity fluctuations known so far for CWC areas were measured in the Cape Lookout CWC habitat. These large temperature and salinity variations are likely to influence the metabolism of the cold-water corals and associated benthic species on the mounds. Furthermore, corals regularly experience abrasive sand storms that occur during each time the Gulf Stream enters the area. Meandering of the Gulf Stream in and out of the research area is the main driver of the near-bed processes near Cape Lookout and influences the whole mound area as events were observed at all lander and mooring stations. Upwelling in cold core eddies and increased productivity in 
these eddies was not observed near the seabed. Only one major fluorescence peak was observed, which might form a food source for the species. Another additional food source might be zooplankton or nutrients derived from zooplankton, which were highly abundant during April and May 2010.

\section{Supplementary material related to this article is available online at http://www.biogeosciences.net/11/ 2543/2014/bg-11-2543-2014-supplement.pdf.}

Acknowledgements. We gratefully acknowledge the assistance of captain, crew and technicians on board the RV Cape Hatteras and the RV Pelagia. Ship time for the Cape Hatteras was provided by the Duke-UNC Oceanographic Consortium (to S. W. Ross). We thank Sharyn Ossebaar-Crayford for help with the organic carbon and nitrogen analysis and Piet van Gaever for help with the ${ }^{210} \mathrm{~Pb}$ analysis. We thank Autun Purser and an anonymous reviewer for their helpful comments and suggestions that helped to improve the manuscript. During her time at MARUM, F. Mienis was funded through the DFG-Research Center/Excellence Cluster "The Ocean in the Earth System". F. Mienis is supported financially by the Innovational Research Incentives Scheme of the Netherlands Organisation for Scientific Research (NWO-VENI).

Edited by: G. Herndl

\section{References}

Akhmetzhanov, A. M., Kenyon, N. H., Ivanov, M., Wheeler, A. J., Shashkin, P. V., and Van Weering, T. C. E.: Giant Carbonate Mounds and Current-Swept Seafloors on the Slopes of the Southern Rockall Trough, in: European Margin Sediment Dynamics, edited by: Mienert, J. and Weaver, P., Springer, Berlin, 203-209, 2003.

Bane, J. M., Brooks, D. A., and Lorenson, K. R.: Synoptic observations of the 3-dimensional structure and propagation of GulfStream meanders along the Carolina continental margin, J. Geophys. Res.-Oceans, 86, 6411-6425, 1981.

Becker, E. L., Cordes, E. E., Macko, S. A., and Fisher, C. R.: Importance of seep primary production to Lophelia pertusa and associated fauna in the Gulf of Mexico, Deep-Sea Res. Pt. I, 56, 786-800, 2009.

Blake, J. A. and Grassle, J. F.: Benthic community structure on the US South Atlantic slope off the Carolinas: Spatial heterogeinity in a current-dominated system, Deep-Sea Res. Pt. II, 41, 835874, 1994.

Brooke, S., Holmes, M. W., and Young, C. M.: Sediment tolerance of two different morphotypes of the deep-sea coral Lophelia pertusa from the Gulf of Mexico, Mar. Ecol.-Prog. Ser., 390, 137144, 2009.

Brooke, S., Ross, S. W., Bane, J. M., Seim, H. E., and Young, C. M.: Temperature tolerance of the deep-sea coral Lophelia pertusa from the southeastern United States, Deep-Sea Res. Pt. II, 92, 240-248, 2013
Correa, T. B. S., Eberli, G. P., Grasmueck, M., Reed, J. K., and Correa, A. M. S.: Genesis and morphology of cold-water coral ridges in a unidirectional current regime, Mar. Geol., 326, 1427, 2012

Davies, A. J. and Guinotte, J. M.: Global Habitat Suitability for Framework-Forming Cold-Water Corals, PloS one, 6, e18483, doi:10.1371/journal.pone.0018483, 2011.

Davies, A. J., Duineveld, G. C. A., Lavaleye, M. S. S., Bergman, M. J. N., van Haren, H., and Roberts, J. M.: Downwelling and deep-water bottom currents as food supply mechanisms to the cold-water coral Lophelia pertusa (Scleractinia) at the Mingulay Reef complex, Limnol. Oceanogr., 54, 620-629, 2009.

Davies, A. J., Duineveld, G. C. A., Van Weering, T. C. E., Mienis, F., Quattrini, A. M., Seim, H. E., Bane, J. M., and Ross, S. W.: Short-term environmental variability in cold-water coral habitat at Viosca Knoll, Gulf of Mexico, Deep-Sea Res. Pt. I, 57, 199 $212,2010$.

De Haas, H., Mienis, F., Frank, N., Richter, T., Steinacher, R., De Stigter, H. C., Van der Land, C., and Van Weering, T.: Morphology and sedimentology of (clustered) cold-water coral mounds at the south Rockall Trough margins, NE Atlantic Ocean, Facies, $55,1-26,2009$.

Deines, K. L.: Backscatter estimation using broadband acoustic doppler current profilers, Proc. of IEEE sixth working conference on current measurements, 249-253, 1999.

De Mol, B., Van Rensbergen, P., Pillen, S., Van Herreweghe, K., Van Rooij, D., McDonnell, A., Huvenne, V., Ivanov, M., Swennen, R., and Henriet, J. P.: Large deep-water coral banks in the Porcupine Basin, southwest of Ireland, Mar. Geol., 188, 193-231, 2002.

De Santo, E. M. and Jones, P. J. S.: Offshore marine conservation policies in the North East Atlantic: Emerging tensions and opportunities, Mar. Policy, 31, 336-347, 2007.

Dodds, L. A., Roberts, J. M., Taylor, A. C., and Marubini, F.: Metabolic tolerance of the cold-water coral Lophelia pertusa (Scleractinia) to temperature and dissolved oxygen change, J. Exp. Mar. Biol. Ecol., 349, 205-214, 2007.

Dorschel, B., Hebbeln, D., Rüggeberg, A., Dullo, W.-C., and Freiwald, A.: Growth and erosion of a cold-water coral covered carbonate mound in the Northeast Atlantic during the Late Pleistocene and Holocene, Earth Planet Sc. Lett., 233, 33-44, 2005.

Dorschel, B., Hebbeln, D., Foubert, A., White, M., and Wheeler, A. J.: Hydrodynamics and cold-water coral facies distribution related to recent sedimentary processes at Galway Mound west of Ireland, Mar. Geol., 244, 184-195, 2007.

Dorschel, B., Wheeler, A. J., Huvenne, V. A. I., and de Haas, H.: Cold-water coral mounds in an erosive environmental setting: TOBI side-scan sonar data and ROV video footage from the northwest Porcupine Bank, NE Atlantic, Mar. Geol., 264, 218 229, 2009.

Duineveld, G. C. A., Lavaleye, M. S. S., and Berghuis, E. M.: Particle flux and food supply to a seamount cold-water coral community (Galicia Bank, NW Spain), Mar. Ecol.-Prog. Ser., 277, 13-23, 2004.

Duineveld, G. C. A., Lavaleye, M. S. S., Bergman, M. J. N., De Stigter, H., and Mienis, F.: Trophic structure of a cold-water coral mound community (Rockall Bank, NE Atlantic) in relation to the near-bottom particle supply and current regime, B. Mar. Sci., 81, 449-467, 2007. 
Freiwald, A., Henrich, R., and Paetzold, J.: Anatomy of a deepwater coral reef mound from Stjernsund, West Finnmark, Northern Norway, in: Cool-water carbonates, edited by: James, N. P. and Clarke, J. A. D., Tulsa, 141-162, 1997.

Garciamoliner, G. and Yoder, J. A.: Variability in pigment concentration in warm-core rings as determined by coastal zone color scanner satellite imagery from the Mid-Atlantic Bight, J. Geophys. Res.-Oceans, 99, 14277-14290, 1994.

Glenn, S. M. and Ebbesmeyer, C. C.: Observations of Gulf Stream frontal eddies in the vicinity of Cape Hatteras, J. Geophys. Res., 99, 5047-5055, 1994.

Gorsline, D. S.: Bottom sediments of the Atlantic shelf and slope of the southern United States, J. Geol., 71, 422-440, 1963.

Grasmueck, M., Eberli, G. P., Viggiano, D. A., Correa, T., Rathwell, G., and Luo, J.: Autonomous underwater vehicle (AUV) mapping reveals coral mound distribution, morphology, and oceanography in deep water of the Straits of Florida, Geophys. Res. Lett., 33, L23616, doi:10.1029/2006GL027734, 2006.

Guihen, D., White, M., and Lundälv, T.: Boundary layer flow dynamics at a cold-water coral reef, J. Sea Res., 78, 36-44, 2013.

Henry, L.-A. and Roberts, J. M.: Biodiversity and ecological composition of macrobenthos on cold-water coral mounds and adjacent off-mound habitat in the bathyal Porcupine Seabight, NE Atlantic, Deep-Sea Res. Pt. I, 54, 654-672, 2007.

Hovland, M. and Mortensen, P. B.: Norske korallrev og prosesser i havbunnen, John Grieg Forlag, Bergen, 1-155, 1999.

Hill, J. C., Gayes, T. G., Driscoll, N. W., Johnstone, E. A., and Sedberry, G. R.: Iceberg scours along the southern US Atlantic margin, Geology, 36, 447-450, 2010.

Hughes, J. A. and Gooday, A. J.: Associations between living benthic foraminifera and dead tests of Syringammina fragilissima (Xenophyophorea) in the Darwin Mounds region (NE Atlantic), Deep-Sea Res. Pt. I, 51, 1741-1758, 2004.

Huvenne, V. A. I., Beyer, A., De Haas, H., Dekindt, K., Henriet, J.-P., Kozachenko, M., Olu-Le Roy, K., and Wheeler, A. J.: The seabed appearance of different coral bank provinces in the Porcupine Seabight, NE Atlantic: results from sidescan sonar and ROV seabed mapping, in: Cold-water Corals and Ecosystems, edited by: Freiwald, A. and Roberts, J. M., Springer Verlag, Berlin Heidelberg, 535-559, 2005.

Huvenne, V. A. I., Masson, D., and Wheeler, A.: Sediment dynamics of a sandy contourite: the sedimentary context of the Darwin cold-water coral mounds, Northern Rockall Trough, Int. J. Earth Sci., 98, 865-884, 2009a.

Huvenne, V. A. I., Van Rooij, D., De Mol, B., Thierens, M., O'Donnell, R., and Foubert, A.: Sediment dynamics and palaeoenvironmental context at key stages in the Challenger cold-water coral mound formation: Clues from sediment deposits at the mound base, Deep-Sea Res. Pt. I, 56, 2263-2280, 2009b.

Jensen, A. and Frederiksen, R.: The fauna associated with the bank forming deepwater coral Lophelia pertusa (Scleractinaria) on the Faroe shelf, Sarsia, 77, 53-69, 1992.

Kenyon, N. H., Akhmetzhanov, A. M., Wheeler, A. J., Van Weering, T. C. E., De Haas, H., and Ivanov, M. K.: Giant carbonate mud mounds in the southern Rockall Trough, Mar. Geol., 195, 5-30, 2003.

Kiriakoulakis, K., Freiwald, A., Fisher, E., and Wolff, G. A.: Organic matter quality and supply to deep-water coral/mound sys- tems of the NW European Continental Margin, Int. J. Earth Sci., 96, 159-170, 2007.

Larsson, A. I., van Oevelen, D., Purser, A., and Thomsen, L.: Tolerance to long-term exposure of suspended benthic sediments and drill cuttings in the cold-water coral Lophelia pertusa, Mar. Poll. Bull., 70, 176-188, 2013.

Lavaleye, M., Duineveld, G., Lundalv, T., White, M., Guihen, D., Kiriakoulakis, K., and Wolff, G. A.: Cold-water corals on the Tisler reef preliminary observations on the dynamic reef environment, Oceanography, 22, 76-84, 2009.

Lee, T. N., Yoder, J. A., and Atkinson, L. P.: Gulfstream frontal eddy influence on productivity of the Southeast US continental shelf, J. Geophys. Res., 96, 22191-22205, 1991.

Leterme, S. C. and Pingree, R. D.: The Gulf Stream, rings and North Atlantci Eddy structures from remote sensing (Altimeter and SeaWiFS), J. Mar. Syst., 69, 177-190, 2008.

Lopez Correa, M., Montagna, P., Joseph, N., Ruggeberg, A., Fietzke, J., Flogel, S., Dorschel, B., Goldstein, S. L., Wheeler, A., and Freiwald, A.: Preboreal onset of cold-water coral growth beyond the Arctic Circle revealed by coupled radiocarbon and Useries dating and neodymium isotopes, Quaternary Sci. Rev., 34, 24-43, 2012.

Lumsden, S. E. and Hourigan, T. F.: The State of the deep coral ecosystems of the United States, NOAA Tech. Memo., 1-365, 2007.

Masson, D. G., Bett, B. J., Billett, D. S. M., Jacobs, C. L., Wheeler, A. J., and Wynn, R. B.: The origin of deep-water, coral-topped mounds in the northern Rockall Trough, Northeast Atlantic, Mar. Geol., 194, 159-180, 2003.

Matrai, P. A., Cooper, D. J., and Saltzman, E. S.: Frontal enhancement of dimethylsulfide concentrations across a Gulf Stream meander, J. Mar. Syst., 7, 1-8, 1996.

Matsumoto, A. K. and Lynch-Stieglitz, J.: Persistence of Gulf Stream separation during the Last Glacial period: implications for current separation theories, J. Geophys. Res., 108, 3174, doi:10.1029/2001JC000861, 2003.

Mienis, F., Van Weering, T., De Haas, H., De Stigter, H., Huvenne, V., and Wheeler, A.: Carbonate mound development at the SW Rockall Trough margin based on high resolution TOBI and seismic recording, Mar. Geol., 233, 1-19, 2006.

Mienis, F., De Stigter, H. C., White, M., Duineveld, G., De Haas, H., and Van Weering, T. C. E.: Hydrodynamic controls on cold-water coral growth and carbonate-mound development at the SW and SE Rockall Trough Margin, NE Atlantic Ocean, Deep-Sea Res. Pt. I, 54, 1655-1674, 2007.

Mienis, F., Duineveld, G. C. A., Davies, A. J., Ross, S. W., Seim, H., Bane, J., and van Weering, T. C. E.: The influence of near-bed hydrodynamic conditions on cold-water corals in the Viosca Knoll area, Gulf of Mexico, Deep-Sea Res. Pt. I, 60, 32-45, 2012.

Mortensen, P. B., Hovlund, M., Brattegard, T., and Farestveit, R.: Deep water bioherms of the scleractinian coral Lophelia pertusa (L.) at $64^{\circ} \mathrm{N}$ on the Norwegian shelf: structure and associated megafauna, Sarsia, 80, 145-158, 1995.

Naumann, M. S., Orejas, C., and Ferrier-Pagès, C.: Species-specific physiological response by the cold-water corals Lophelia pertusa and Madrepora oculata to variations within their natural temperature range, Deep-Sea Res. Pt. II, 99, 36-41, 2014.

Neumann, A. C., Kofoed, J. W., and Keller, G. H.: Lithoherms in the Strait of Florida, Geology, 5, 4-10, 1977. 
NOAA National Geophysical Data Center, US Coastal Relief Model, available at: http://www.ngdc.noaa.gov/mgg/coastal/crm. html, 2013.

Partyka, M. L., Ross, S. W., Quattrini, A. M., Sedberry G. R., Birdsong T. W., and Potter J.: Southeastern United States Deep Sea Corals (SEADESC) Initiative: a Collaborative Effort to Characterize Areas 10 of Habitat-Forming Deep-Sea Corals, NOAA Technical Memorandum OER 1, 1-176, 2007.

Paull, C. K., Neumann, A. C., Am Ende, B. A., Ussler III, W., and Rodriguez, N. M.: Lithoherms on the Florida-Hatteras slope, Mar. Geol., 166, 83-101, 2000.

Phillips, S. J., Anderson, R. P., and Schapire, R. E.: Maximum entropy modeling of species geographic distributions, Ecol. Model., 190, 231-259, 2006.

Pinet, P. R. and Popenoe, P.: Shallow seismic stratigraphy and post-Albian geologic history of the northern and central Blake Plateau, Geol. Soc. Am. Bull., 96, 627-638, 1985.

Pinet, P. R., Popenoe, P., and Nelligan, D. F.: Gulf-Stream - reconstruction of Cenozoic flow patterns over the Blake Plateau, Geology, 9, 266-270, 1981.

Pratt, R. M.: Bottom currents on the Blake Plateau, Deep-Sea Res., 10, 245-249, 1963.

Pratt, R. M. and Heezen, B. C.: Topography of the Blake Plateau, Deep-Sea Res., 11, 721-728, 1964.

Purser, A., Larsson, A. I., Thomsen, L., and van Oevelen, D.: The influence of flow velocity and food concentration on Lophelia pertusa (Scleractinia) zooplankton capture rates, J. Exp. Mar. Biol. Ecol., 395, 55-62, 2010.

Quattrini, A. M., Ross, S. W., Carlson, M. C. T., and Nizinski, M. S.: Megafaunal-habitat associations at a deep-sea coral mound off North Carolina, USA, Mar. Biol., 159, 1079-1094, 2012.

Raes, M. and Vanreusel, A.: Microhabitat type determines the composition of nematode communities associated with sedimentclogged cold-water coral framework in the Porcupine Seabight (NE Atlantic), Deep-Sea Res. Pt. I, 53, 1880-1894, 2006.

Reed, J. C.: Distribution and structure of deep-water Oculina Varicosa coral reefs of Central and Eastern Florida, B. Mar. Sci., 30, 667-677, 1980 .

Reed, J. K., Weaver, D. C., and Pomponi, S. A.: Habitat and fauna of deep-water Lophelia pertusa coral reefs off the southeastern US: Blake Plateau, Straits of Florida, and Gulf of Mexico, B. Mar. Sci., 78, 343-375, 2006.

Reed, K. R.: Comparison of deep-water coral reefs and lithoherms off Southeastern USA, Hydrobiologia, 471, 57-69, 2002.

Roberts, J. M., Wheeler, A., and Freiwald, A.: Reefs of the Deep: The Biology and Geology of Cold-Water Coral Ecosystems, Science, 312, 543-545, 2006.

Ross, S. W. and Nizinski, M.: State of the deep coral ecosystems in the U.S. southeast region: Cape Hatteras to southeastern Florida, in: The state of deep coral ecosystems of the United States, edited by: Lumsden, S. E., Hourigan, T. F., Bruckner, A. W., and Dorr, G., NOAA Technical Memorandum CRCP-3, Silver Spring, MD, 233-270, 2007a.

Ross, S. W. and Quattrini, A. M.: The fish fauna associated with deep coral banks off the southeastern United States, Deep-Sea Res. Pt. I, 54, 975-1007, 2007b.

Ross, S. W. and Quattrini, A. M.: Deep-sea reef fish assemblage patterns on the Blake Plateau (Western North Atlantic Ocean), Mar. Ecol., 30, 74-92, 2009.
Ryan, J. P. and Yoder, J. A.: Long-term mean and event-related pigment distributions during the unstratified period in South Atlantic Bight outer margin and middle shelf waters, Cont. Shelf Res., 16, 1165-1183, 1996.

Ryan, J. P., Yoder, J. A., Barth, J. A., and Cornillon, P. C.: Chlorophyll enhancement and mixing associated with meanders of the shelf break front in the Mid-Atlantic Bight, J. Geophys. Res.Oceans, 104, 23479-23493, 1999.

Ryan, J. P., Yoder, J. A., and Townsend, D. W.: Influence of a Gulf Stream warm-core ring on water mass and chlorophyll distributions along the southern flank of Georges Bank, Deep-Sea Res. Pt. II, 48, 159-178, 2001.

Serpetti, N., Gontikaki, E., Narayanaswamy, B. E., and Witte, U.: Macrofaunal community inside and outside of the Darwin Mounds Special Area of Conservation, NE Atlantic, Biogeosciences, 10, 3705-3714, doi:10.5194/bg-10-3705-2013, 2013.

Sheridan, R. E.: Sedimentary basins of the Atlantic margin of North America, Tectonophysics, 36, 113-132, 1976.

Tong, R., Purser, A., and Unnithan, V.: Predicting habitat suitability for cold-water coral Lophelia pertusa using multiscale terrain variables,in: Earth System Science: Bridging the Gaps between Disciplines, edited by: Lohmann, G., Grosfeld, K., WolfGladrow, D., Unnithan, V., Notholt, J., and Wegner, A., Springer, Heidelberg, 113-118, 2013.

Van Gaever, S., Vanreusel, A., Hughes, J. A., Bett, B. J., and Kiriakoulakis, K.: The macro- and micro-scale patchiness of meiobenthos associated with the Darwin Mounds (north-east Atlantic), J. Mar. Biol. Assoc. UK, 84, 547-556, 2004.

Van Oevelen, D., Duineveld, G., Lavaleye, M., Mienis, F., Soetaert, K., and Heip, C. H. R.: The cold-water coral community as a hot spot for carbon cycling on continental margins: A food-web analysis from Rockall Bank (northeast Atlantic), Limnol. Oceanogr., 54, 1829-1844, 2009.

Vanreusel, A., Fonseca, G., Danovaro, R., Da Silva, M. C., Esteves, A. M., Ferrero, T., Gad, G., Galtsova, V., Gambi, C., Da Fonsêca Genevois, V., Ingels, J., Ingole, B., Lampadariou, N., Merckx, B., Miljutin, D., Miljutina, M., Muthumbi, A., Netto, S., Portnova, D., Radziejewska, T., Raes, M., Tchesunov, A., Vanaverbeke, J., Van Gaever, S., Venekey, V., Bezerra, T. N., Flint, H., Copley, J., Pape, E., Zeppilli, D., Martinez, P. A., and Galeron, J.: The contribution of deep-sea macrohabitat heterogeneity to global nematode diversity, Mar. Ecol., 31, 6-20, 2010.

Van Rooij, D., De Mol, B., Huvenne, V., Ivanov, M., and Henriet, J.-P.: Seismic evidence of current-controlled sedimentation in the Belgica mound province, upper Porcupine slope, southwest of Ireland, Mar. Geol., 195, 31-53, 2003.

Van Soest, R. W. M., Cleary, D. F. R., De Kluijver, M. J., Lavaleye, M. S. S., Maier, C., and Van Duyl, F. C.: Sponge diversity and community composition in Irish bathyal coral reefs, Contribut. Zool., 76, 121-142, 2007.

Van Weering, T. C. E., De Haas, H., Akhmetzhanov, A. M., and Kenyon, N. H.: Giant carbonate mounds along the Porcupine and SW Rockall Trough margins, in: European margin sediment dynamics, edited by: Mienert, J. and Weaver, P., Springer, Berlin, 211-216, 2003a

Van Weering, T. C. E., De Haas, H., De Stigter, H. C., LykkeAndersen, H., and Kouvaev, I.: Structure and development of giant carbonate mounds at the SW and SE Rockall Trough margins, NE Atlantic Ocean, Mar. Geol., 198, 67-81, 2003 b. 
Wheeler, A. J., Kozachenko, M., Henry, L. A., Foubert, A., de Haas, H., Huvenne, V. A. I., Masson, D. G., and Olu, K.: The Moira Mounds, small cold-water coral banks in the Porcupine Seabight, NE Atlantic: Part A - an early stage growth phase for future coral carbonate mounds?, Mar. Geol., 282, 53-64, 2011.

White, M., Mohn, C., De Stigter, H. C., and Mottram, G.: Deepwater coral development as a function of hydrodynamics and surface productivity around the submarine banks of the Rockall Trough, NE Atlantic, in: Cold-water corals and ecosystems, edited by: Freiwald, A. and Roberts, J. M., Springer-Verlag, Berlin, 503-514, 2005.
Yesson, C., Taylor, M. L., Tittensor, D. P., Davies, A. J., Guinotte, J., Baco, A., Black, J., Hall-Spencer, J. M., and Rogers, A.D.: Global habitat suitability of cold-water octocorals, J. Biogeogr., 39, 1278-1292, 2012. 